https://helda.helsinki.fi

Critique of development economics

\title{
Obeng-Odoom, Franklin
}

2019-06-14

Obeng-Odoom , F 2019 , ' Critique of development economics ', The Japanese political economy, vol. 44 , no. 1-4 , pp. 59-81 . https://doi.org/10.1080/2329194X.2019.1617637

http://hdl.handle.net/10138/340847

https://doi.org/10.1080/2329194X.2019.1617637

acceptedVersion

Downloaded from Helda, University of Helsinki institutional repository.

This is an electronic reprint of the original article.

This reprint may differ from the original in pagination and typographic detail.

Please cite the original version. 


\title{
Critique of Development Economics
}

\author{
Franklin Obeng-Odoom \\ Development Studies and Helsinki Institute of Sustainability Science \\ University of Helsinki, Finland \\ franklin.obeng-odoom@helsinki.fi
}




\begin{abstract}
Development economics has struggled to understand the conditions of Africa and Africans. However, the nature of this critique, the alternative to development economics, and the challenges of the existing revisionism of today have not, as yet, received the attention of political economists. As this body of work is relevant to the current debates on Africa's underdevelopment, and development economics more generally, the present paper attempts to fill this gap. The paper accepts the classic criticisms that mainstream development economics does not provide an effective approach to studying inequality, that it is Western centric in both its concepts and vision of the good society, and that these analytical problems have contributed to worsening social conditions in Africa because they have shaped African development policy. However, the paper departs from the existing approaches of locating these problems in the realm of ideas and looks to the nexus between ideas, materialism, and history. So, the widespread view that it is the reliance on problematic concepts and on unreliable official statistics that constitute the sources of these problems is questioned. Instead, the present paper extends the premise to both the ontology and the central methodology of mainstream development economics. I caution against the preference for an Indigenous economics as panacea and the revisionism of today, that is, the push for a marriage between anthropology and economics. While clearly much stronger on analysing entire economic systems and, indeed, on addressing some of the classical problems in development economics, the alternatives do not succeed in probing inter-group inequalities. The development of the emergent field of stratification economics by black political economists is defended as a more fruitful alternative.
\end{abstract}

Key Words: Africa, Development Economics, Indigenous Economics, Stratification Economics 


\section{Introduction}

Development Economics, the main source of inspiration for analysing widespread inequality in Africa (see, for example, Killick, 1980; 2010; Bigsten, 2018), is not fitfor-purpose. The nature of its problems requires urgent exposition because inequalities of various shades in Africa have not only persisted; they have also increased (see, for example, Osei-Assibey, 2014; Obeng-Odoom, 2015a).

Development economists themselves have intensified their studies of Africa, but the vast body of research has mostly focused on what is wrong with Africa itself. Alfred Marshall (1890), in Principles of Economics, focused on defects in Africa when he claimed that the continent is backward because of its savage cultures and harsh climate, together with the poor working habits of Africans. Indeed, according to Peter Bauer (1971), Margaret's Thatcher's Economic Advisor, Africans had "those attitudes and customs which most inhibit material advance" (Bauer, 1971:38). Africans, he continued, lack "administrative skills, thrift, the ability to perceive and take advantage of economic opportunity, and various other aptitudes and attitudes, derived, in part from the background of societies long accustomed to the ways of a money economy" (Bauer, 1971:347). Modern neoclassical economists, under the aegis of the World Bank and the IMF, have been similarly oriented, even if a more politically correct (see, for example, Collier, 2006, 2008, 2009).

Development economists of a radical orientation have focused, instead, on the relationship between Africa and the rest of the world (see, for example, Amin, 1977; Robinson, 1979/2009; Rodney, 1972/2011). Alongside this critical tradition is a more liberal "history of economic thought" literature, looking at the evolution of the idea of economic development (see, for example, Arndt, 1987; Austin, 2016).

The state of the literature can, therefore, be summarised by "Lord Bauer's Rule for Studying Economic Stagnation":

Economic Achievement and progress depend largely on human aptitudes and attitudes, on social and political institutions and arrangements which derive from these, on historical experience, and to a lesser extent on external contacts, market opportunities and on natural resources. And if these factors favourable to material progress are present, persons, groups and even societies will not stagnate, so that it is the absence of the favourable determents, and not poverty, which is the causal factor in prolonged stagnation (Bauer, 1971: 41).

An extensive literature has emerged to evaluate the claims in the various domains of research (see, for example, Emig, 1999; Sen, 1999; Alagidede, 2011, 2012; Asongu, 2014; 2016; Asongu and De Moor, 2017; Bigsten, 2018). This Ping-Pong on Africa's development, and development economics, continues to-day within Lord Bauer's Rule.

Analysing what is wrong with the canon of knowledge on which African bureaucrats have drawn for managing their economies is, however, relatively undeveloped. For 
example, in addressing the question "What's wrong with economics?", the contributors to the special issue of Journal of Australian Political Economy, did not focus on development economics at all (for an overview of the issue, see Stilwell, 2018). So, it is important to ask "what is wrong with development economics?" What alternatives exist to it, and in what ways can these alternatives be developed further?

To answer these questions, the present paper follows William Waller's (2017) approach in using major books in political economy as 'case studies'. In this regard, Polly Hill's ground-breaking book, Development Economics on Trial: The Anthropological Case for a Prosecution, is a useful case. Although in the days in which development economics was defining its character a few articles were written about unreliable statistics and the inapplicability of certain concepts (see, for example, Neale, 1959; Robinson, 1960), Hill's book, focused on the entire field of development economics.

In a field dominated by male development economists, from its origins to date (Schmelzer, 2016), making it not only "mainstream" but also "malestream", Polly Hill's work provides a refreshing alternative. Focusing on Hill's book is useful for three additional reasons. First, in spite of its rich insights, it is not widely known among political economists, who tend to be more familiar with the work of Joan Robinson, Hill's Ph.D. supervisor, and certainly the work of Robinson's two students; Joseph Stiglitz and Amartya Sen (see, for example, Sen's conversation with Arjo Klamer in Klamer, 1989); but not her hybrid protégé, Poly Hill (1914-2005) who sought to blend economics and social anthropology. Second, Hill's approach does not just provide a critique; it also proposes an alternative to mainstream development economics and, hence, fulfils the aspiration of political economy to become an alternative approach to mainstream economics (see, for example, Butler, 2002; Stilwell, 2018). Third, unlike others such as Walter Rodney and Samir Amin who did not try to found an alternative school of economics, Polly Hill tried to articulate the outlines of such a school, using experiences from both Africa and Asia, an approach that has recently been advocated by some Japanese political economists (see, for example, Shin-Kap, Sang-Jic, and Yun-Joo, 2014).

Based on this approach, the paper accepts Poly Hill's criticisms that mainstream development economics does not provide an effective approach to studying inequality, that it is Western centric in both its concepts and vision of the good society, and that these analytical problems have contributed to worsening social conditions in Africa because they have shaped African development policy. However, the paper departs from Hill's approach, and the approaches of recent scholars, centred on locating these problems in the realm of ideas and, instead, looks to the nexus between ideas, materialism, and history as a more compelling alternative explanation. From this perspective, the widespread view that it is the reliance on problematic concepts and on unreliable official statistics that constitute the sources of these problems is questioned. Instead, the present paper extends the critique to both the ontology and the central methodology of mainstream development economics. In turn, this paper cautions against Hill's preference for an Indigenous economics as panacea and the revisionism of today, that is, the push for 
a marriage between anthropology/history and economics. While clearly much stronger on analysing entire economic systems and, indeed, on addressing some of the classical problems in development economics, these alternatives do not succeed in probing inter-group inequalities. The development of the emergent field of stratification economics by black political economists is defended as a more fruitful alternative.

The rest of the paper is divided into five sections. Critique of Development Economics (section 2) contextualises Hill's central concerns with this field of economics. Following that diagnostic analysis, Addressing the Problem (section 3) analyses Hill's posited alternatives to existing approaches in development economics. Assessing Polly Hill's Political Economy (section 4) provides an examination of Hill's proposals, while W(h)ither Development Economics (section 5) offers an assessment of modern alternatives to Polly Hill's political economy.

\section{Critique of Development Economics}

Ever since the invention of development economics as the economics that would make the West feel good about itself (Galbraith, 1979), development economicus has faced serious analytical challenge. The field's double, and often shifting, standards have been the source of critical engagement (Arndt, 1987). Much of this dialogue, however, has been in the nature of criticisms; not critiques. So, the contributions of Joseph Stiglitz, Kaushik Basu, and Andrew Foster, for example, seek to rethink development economics, but mainly along the lines of the mainstream, neoclassical school. Others, such as Amartya Sen, bring into economics deeper philosophical reflections on ethics and freedom, but they still remain within the strictures of methodological individualism (Gore, 1993, 1997). In this regard, rethinking development economics has often taken the form of doing better neoclassical economics, envisioning a new institutional economics, and experiments with behavioural economics (see, for example, Sen, 1999; Boettke et al., 2008).

More radical critiques have been developed, of course. Scholars in the Global South, in particular, have provided full-throated critiques, with Walter Rodney, Issa Shivji, Thandika Mkandawire, and Samir Amin as some of the leading voices (see, Rodney, 1972/2011; Shivji, 1976, 2017; Mkandawire, 2015; Amin, 1974, 1977, 2014). However, apart from a few respectable exceptions (see, for example, Zouache, 2017; 2018), Vishnu Padayachee's (1998) and Adam Mayer's (2016) fine anthologies show that these existing critiques are rooted within various strands of Marxist economics (see also, Akbulut et al, 2015).

Polly Hill's principal challenge to development economics is rather different. It can be said to be a challenge to both mainstream neoclassical and radical Marxist development economics. Built on both conceptual and pragmatic lines of thought, Hill argues that development economics tends to make conceptual mistakes, tends to over-rely on official statistics, and tends to neglect inequalities. In her words, she sought "to expose what I see as the old-fashioned, stereotyped, Western-biased, 
overgeneralized crudity and conceptual falsity of so many conventional economic premises, as well as economists' complacent attitude to bad official statistics" (Hill, 1986: xi).

Conceptual mistakes are fundamental to Hill's critique. Consider her critique of the idea of "household" used in development economics. Pointing to substantial heterogeneity within households in Africa, she concludes that the view - now, wellknown but still hegemonic (for a discussion, see Hewitson, 2011: 96-100) - of a uniformly patriarchal household is the norm is a myth. Hill shows that many women are both empowered, have considerable agency, and pursue independent economic strategies. If so, a central assumption in neoclassical development microeconomics becomes shaky.

Hill's critique of the notion of "peasant" was, instead, directed at Marxist economics. If the image of a peasant is someone struggling, then, according to Hill, the idea does not apply to most of the people called peasants because so-called peasants have much income from non-agrarian sources, which they combine with incomes from agrarian activities. So, these people are not strugglers. Likewise, if the idea of a peasant refers to a group of people with a shared revolutionary motive, then again, the designation is a misnomer because, in practice, peasants are so different that a shared objection to a common enemy is not often apparent.

These conceptual critiques lead to Hill's second concern: development economists' blind faith in statistics and the techniques for analysing it. For Hill, the concepts used by statisticians are usually meaningless and they often misrepresent the landless and the powerless in Africa either by overlooking, or by undercounting, such groups (see, for example, Hill, 1986: 43 and 48). In essence, the available official statistical information is not reliable. If so, regardless of the rigor in the technique for analysing the data, the results are likely to be questionable. Indeed, Hill argues that the more sophisticated the techniques, the less meaningful the results. In her words:

It is not fanciful to insist that as the sophistication of "data processing" increases, so the quality of the finished statistical product declines. Increasingly, so far as the rural third world is concerned, the power lies with those who have become so astoundingly proficient in manipulating the figures they receive "from below" with the eager people who derive so much enjoyment from the advanced electronics. Infatuated by their technology, it is beneath their dignity to contemplate the inherent unreliability of their "basic data" - and their resultant impotence is never contemplated. Consequently, all the commands come from above, and the less ambitious, and far less clever, "data collectors" cower underneath. How can the international world be persuaded that the problems of collecting statistics, and allied material, at the ground level in the third world, are just as intellectually challenging, and far more important, than mere mathematical processing? (Hill, 1986: 48 -49, italics and quotation marks in original). 
Hill is not against the use of statistics or "mathematical processing" per se. What she is against is trying to use ever more sophisticated mathematical techniques to solve fundamental data and ontological problems. Applied to the study of inequality, Hill argues that development economics tends to neglect (a) fractions within the household, (b) the study of inheritance and the transmission of wealth, and (c) women's experiences. In this sense, development economics is centrally focused on quantitative growth without looking at its differential impacts on different identities (especially gender), and how those impacts are transmitted through generations. Related to "The Golden Age Fallacy", this problem - elaborated in chapter 6 of Hill's magnum opus, Development Economics on Trial - is what Hill calls the myth of "Aboriginal equilibrium" or the idea that there was "equality at the base". The effect of this assumption is that neoclassical development economists do not attach much seriousness to the study inequality in rural areas because they assume that it does not exist, while Marxist economists only claim that such inequality is imposed by external factors.

The consequences of these conceptual and pragmatic problems are serious enough to unsettle society and economy. Hill identifies problems such as research that takes us nowhere, economics that misinforms or hides reality by neglecting it, and policy mistakes ${ }^{1}$ that make the problems they intend to solve worse (see, for example, Hill, 1986, chapters 2-4). Development economics also peddles much misinformation, including the misleading claim that rural economies are entirely agrarian when, in fact, there are non-agrarian economic activities. Likewise, the emergence of trade, in particular the idea that "barter" is the first stage of economic exchange is not necessarily accurate because, as Hill argues, even in advanced capitalist societies, barter does not necessarily go away.

Contrary to what Neale and Viar (1989) claim, Hill is not a population explosion denialist. Rather, she contests the idea that it is population explosion that underpins the problems of the Global South (Hill, 1986: 60-65). Political-economic factors are more important, according to Hill. Indeed, population growth could also be benign for Africa, a point better developed in Hill's book, The Migrant Cocoa-Farmers of Southern Ghana (Hill, 1963), which demonstrates that the world leading cocoa industry in Ghana is, indeed, developed largely by migrants.

\section{Addressing the Problems}

Hill's proposed approach to addressing the problems identified is to take anthropology seriously because its research approach, far better appreciation of real-world conditions, and propensity for collaboration with local community

\footnotetext{
${ }^{1}$ For example, the bias of mainstream economists for mechanical farming - based on the assumption that small scale farming is inefficient (see, for example, Hill, 1986, chapter 2) - has led policy makers to neglect, and to reject, small scale farming. Yet, as Hill shows in Development Economics on Trial (1986) and throughout her career (see, for example, Hill, 1963, 1966), such farms can be, and often have been, socially efficient. Indeed, the cocoa farming of West Africa is done on small scale basis, but it is able to supply the world with its cocoa needs.
} 
members can help to both address, and transcend, the shortfalls of development economics. This praise for anthropology is signalled in the subtitle of her book, 'The Anthropological Case for Prosecution'. Elaborated in chapters 6 to 14 of Development Economics on Trial, the anthropological solution is defended against possible criticisms. So, Hill notes that it is possible for interviews to misinform, but she shows acute awareness of the problem. As an example of how to address that problem, she describes instances in which she had to rely on people with a better memory of what happened to others (migrants) than the migrants themselves.

This triangulation would become necessary, she suggests, when the memory of the migrants being interviewed has faded or that the migrants have imbibed new discourses that were not related to their true motive for migrating. Crosschecking from other sources is also important when the original motive of migrants have evolved in ways that other relatives can better explain. So, there are ways of insulating anthropology from such problems. Indeed, anthropologists also do close observations to complement the data from interviews. Hill claims that anthropologists are more respectful of economists, so they tend to engage the work of economists more. While, as Hill notes, anthropologists are accused of pedestrian observations about the particular, she contends that anthropologists can, and often do, generalise. So, the case against anthropologists is dismissed, while that against economists is upheld.

For Hill, "my constructive purpose, which takes up much more space, is a practical demonstration that many of the findings of the less esoteric branches of economic anthropology ought to be regarded as highly relevant to development economics although, as any glance at economists' bibliographies shows, they are habitually ignored" (Hill, 1986: xi). Hill offers concrete examples of what anthropological research can add. In respect to the "Golden Age Fallacy", for example, Hill's anthropology leads her to the following conclusions:

My two purposes in this brief chapter are first to argue, on general principles, that 'inequality at the base date' ought to be our starting point, such village inequality being perpetuated indefinitely; and second to insist that the findings of economic anthropologists invariably show that village inequality is pronounced (Hill, 1986:70 -71 , italics in original quotation).

Hill, was seeking 'merely to build bridges between economic anthropology and development economics' (Hill, 1986: xi). So, in her "plea for indigenous economics", published in Economic Development and Cultural Change, Hill tries to offer the outlines of a replacement for development economics or, as she put it, "the study of indigenous economies" (Hill, 1966: 10). This economics must be designed for 'underdeveloped regions such as West Africa' (Hill, 1966: 10).

The vision of "indigenous economics" is improving the quality of life; not just pursuing quantitative changes in the size of the economy, which is the vision of neoclassical development economics. While the mainstream development economist assumes 
that subsistence production and fragmented land development are inefficient, these features do not necessarily mean inefficiency for people in Indigenous economies. Their quality of life, in fact, can be enhanced by these so-called inefficiencies. As Indigenous socio-economic systems nurture institutions or social processes/practices that complement the perceived deleterious conditions of subsistence and fragmentation. Indeed, the so-called subsistence is usually accompanied by some trade. Farming systems, devalued in mainstream economics, are valuable for this reason, but also because they have their own social logic and demonstrable economic efficiency. For instance, because cocoa farms take a while to yield fruits and returns, farmers plant cocoyam and plantain alongside cocoa which are also good cover crops for cocoa seedlings (Hill, 1986: 18-20).

Hill's proposed indigenous economics is not centred on "cultural factors" - the focus of most anthropological enquiry today. Thus, it is a different kind of anthropology that she seeks to bring into development economics. Like human beings elsewhere, Hill argues, Africans are rational. In this sense, cultural explanations of the conditions of the poor are rejected. If the behaviour of people in these regions appear different, it is because of the nature of their economies.

This rational behaviour, Hill argues, must be understood in context. For example, individual cocoa farmers struggle to obtain finance, so they form "companies" which, in turn, are used to attract funds. For Hill (1963), three key points emerge from the analysis of companies. First, Africans are rational, much like others who are accepted in development economics as rational actors. Second, the rationality to cooperate for funding ought to be understood in context. Third, group and collective activities can drive, rather than impede, progress (see, for example, Ottenberg, 1964:1434).

Hill argued that the poor show no tendency for free, autonomous choice, however. So, the neoclassical-informed public choice idea that workers in informal economies 'voluntarily' choose such work is simplistic (see, for example, Gërxhani, 2004). In her words, "Perhaps the main reason why economic generalizations should never cover both rich and poor cultivators is that the latter are not free to choose between various options, being always under duress; the small minority of rich people are those who make all the important decisions, while the others trail behind for ever adjusting themselves to hopeless situations. The point is that the struggling poor are a universal phenomenon, not an anomaly. It is the failure to appreciate this, and the refusal to study "ordinary village" poverty for what it is, on the ground, which accounts for the general panic aroused by the thought that externally encouraged 'rural development' invariably enhances incipient inequality to an unacceptable degree" (Hill, 1986: 28-29).

In this sense, the role of the indigenous economist is not to pursue cultural explanations. Rather, it is to first identify myths or, what Hill calls, 'economic folklore', about indigenous economist and the conditions of indigenous peoples. Second, challenge these myths by calling them into question on logical and or substantivist grounds, and third pursuing alternative economic analysis in the substantivist tradition (Hill, 1966:11). In this approach, the indigenous economist must recognise 
that the compartmentality of economic life a study of which takes time. In this process:

If the investigator is a social anthropologist, then he must understand the necessity of isolating economic factors; he must also be prepared to use every opportunity of hinging the material he collects either to already existing statistics) or to other broadly based, administratively organized data, such as farm maps, nominal rolls, etc.), or in the last resort (in the absence of existing material) to collect a minimum of simple figures himself. If, however, the investigator is an economist, he should usually discard his traditional procedure of collecting most of his material through field assistants, using questionnaires, in favour of a method, learned from anthropologists, which mainly relies on questioning and observing individuals while they are at work. Market women should be interviewed in markets, lorry drivers in lorry parks, farmers on their farms (or at their houses), fishermen on the beach. The procedure should be semi-statistical, in the sense that similar, even identical, questions should be put to many informants independently, with a view to comparing, or even totalling, their replies (Hill, 1966:16)

Hill insists that the investigator 'must have a point of view' in order to make judgment (Hill, 1966:16-17). So, here, there is room for theory but direct observation or experience is needed or, at least, it is useful to rely on the account of those who have directly experienced on the processes of social change in underdeveloped regions. Official statistics is useful and, for issues that require large-scale investigations, even more useful, as governments usually have a better capacity to collect large scale statistics than individual investigators. However, the use of such statistics must go with an appreciation of context.

To execute this task effectively, Hill's advice is to develop Indigenous economics or, to pursue the more modest proposal emphasised by T.S. Epstein (1975) for a 'marriage' of anthropology and economics. Stefan Kesting's (2018) recent contribution to the Forum for Social Economics provides a detailed history of this economic anthropology. An Indigenous economics remains a dream, but it is slowly gaining momentum, while to-day, the journal, Economic Development and Cultural Change continues to advocate interdisciplinary work between economics and anthropology. Even this modest proposal has been rejected, especially by development economists. So, in Economic Anthropology, Chris Hann and Keith Hart (2011), two leading anthropologists, seek "to bring the two closer together". But should the solution be bringing economics and anthropology together, or is it better to develop, in the words of Hill, an "Indigenous economics"?

\section{Assessing Polly Hill's Political Economy}

Although provocative and eloquent, Hill's attempt to rework development economics is not necessarily coherent. Indeed, it is contradictory in four respects. The first is a slippage in her analytical terminologies. Her claims about peasants could have been 
more explicitly expressed as a critique aimed at Marxists or some anthropologists; not neoclassical development economists whose unit of analysis tends to be individuals, firms, and households. In other words, Hill's work could instead be called, "anthropology on trial, the development economics case for a prosecution". While Hill might be defended on grounds that Marxist economics is strong on the use of that concept too, Hill set out to write a critique of mainstream development economics; not Marxist economics. She, however, does sometimes explicitly criticise Marxist economics too which, in turn, compounds the contradictions in Hill.

Is she against neoclassical or Marxist economics? If the latter, then the concept of household is useless; and if the former then the criticism about peasants is misplaced. Hill shows grave inconsistencies when she writes (Hill, 1966: 12) that "In West Africa, nowadays, the educated urban classes, notably the politicians, increasingly refer to farmers as "peasants"'. So, is it economists, Marxists, or politicians who are guilty of using the concept? Her own reconciliation is that "When West African politicians deplore, as they so often do, the backwardness of farm people, they are unaware of the extent to which they are echoing the conventional ignorance of economists" (Hill, 1966: 12). Again, this statement does not prove that it is mainstream economists who use the idea of peasants.

A second weakness is more fundamental. As she does not show that the problems, she identifies are inherent in the mainstream economics models themselves, her analysis is incomplete. Hill's approach of using individual textbooks to show her concerns with mainstream economics has its strengths (e.g., textbooks can represent the state of knowledge and gives direction to newcomers into the field). However, doing so impedes her ability to demonstrate that, a central part of the weaknesses in mainstream development economics is its methodologies. According to Neale and Viar (1989), Hill's key methodological challenge should have been to point to the formalist-substantivist debate about whether society is better studied through crude formalist (expressed in deductive thinking and mathematical equations) or through real world substantivism (see, for example, Polanyi, 1957).

It is clear, however, that such a concern is part of Hill's critique. In her own words, "While it is common knowledge that so many of the assumptions on which rural development economists base their work are thoroughly unrealistic, owing to their general lack of experience of the tropical world, no one seems to be prepared to assume the role of outside professional critic" (Hill, 1986: xi., emphasis added).

Yet, an unrecognised issue is the role of material interests in economics and how, for example, landed interests have tried to, and succeed in controlling, the direction of mainstream development economics (see, for example, Foldvary, 2008; ObengOdoom, 2013, 2016; Schmeizer, 2016). So, Hill's point should be that (a) lack of experiences/Americo-Eurocentric experiences, (b) the 'fetishisation' of formal models, and (c) the role of ideology combines to control development economics and to give misleading insights. 
The third critique of Hill is her blind faith in economic anthropology. Anthropology was a colonial project, often collaborating with empire to subjugate Africa and Africans. So, after independence, it became part of the vanquished established order and, hence, survived mainly by studying African cultures. In seeking to make amends to Africans by supporting so-called "participatory development", it has, perhaps, created even more problems (Nyamnjoh, 2012). Indeed, even in terms of offering analytical compass to the body of work on participation, anthropology has collaborated with empire and achieved imperial ambitions, as we see in the role of anthropologists in influencing local acceptance of highly problematic Ebola measures administered by the WHO and other world development agencies (Obeng-Odoom and Marke, 2018). While some anthropologists rely on economic analyses, or partner with economists (see, for example, Macdonald and Spruyt, 2014), many anthropologists are also quite closed to other fields (Hann and Hart, 2011), while others are not necessarily antithetical to mainstream economics model (Kesting, 2018:5). It is, indeed, simplistic for Hill to suggest that economists do not rely on anthropological work at all. In practice, much new institutional economics does precisely what Hill sought (Neale and Viar, 1989).

To this day, that field has become an avenue for many economic anthropologists and economists. For these economic anthropologists or anthropological economists, Hill's claim that the detail in the work of anthropologists is not an end in itself but rather a means to a bigger end of generalisation (Hill, 1986: xi) is accurate. Their methodology is akin, in essence, to mainstream economics - even if they focus more on transactions rather than choice (see, for example, Boettke, Fink, and Smith, 2012). As with mainstream economists, their history (see, for example, Alchian and Demsetz, 1973; Acemoglu and Robinson, 2012) has been found (see, for example, Chang, 2011a, 2011b; Milonakis and Meramveliotakis, 2013) to be typically compressed, their appreciation of economic systems quite weak, and their bias for Americo-Eurocentrecism in their account of economic development very strong.

Fourth, neither Hill nor the revisionists succeed in analysing intergroup differences. Hill's real genius is looking at inequalities within groups, between women and men, and between different people within the household. But analysing inequality between groups whether locally, nationally, regionally, or globally together with probing the intersections across scales and groups is one of the major weakness in Hill's challenge to development economics.

Focusing on development economics is important, of course, but the neglect of economic structure and material interest in analysing inequality is a major weakness too. If development economics is the only source of the problem, then why do different groups have diverse experiences under similar conditions? Hill neither succeeds in analysing race, different groupings, nor imperial forces that impinge differently on diverse groups and creating inter-group income and wealth differences (see, for example, Hill, 1963; 1986). As Simon Ottenberg (1964:1435, italics in 
original) noted in reviewing her book, the Migrant Cocoa-Farmer from Southern Ghana (Hill, 1964):

...it is not clear why, for example, the patrilineal ones did not use agnatic descent groups rather than villages as the basis of the company, nor even why the matrilineal peoples, who also lived in villages, failed to use this local community as a basis for economic organization. Nor is the question fully explored as to why the people in the forest areas among whom the people of the Akwapim Ridge moved did not themselves engage more fully in the cocoa industry. And one could ask for a concluding chapter in which some awareness is shown that similar economic myths have been decimated elsewhere, and of how her study relates to such reports. It is as if she, like the Akwapim, ventured on a long voyage unaware, and apparently unconcerned, that other voyageurs exist in the universe.

Yet, unlike Ottenberg (see, 1964: 1434 -1435) who claims that this problem arose because of Hill's lack of access to anthropological material (a contradiction because Hill would argue she relied on anthropological data), it is, as can be seen in Ottengberg's own criticism, a methodological weakness arising from Hill's own compartmentalised approach to inequality. If so, neither mainstream development economics (neoclassical, new institutional, or a mixture of them), Marxist development economics, nor Hill's indigenous economics is a formidable alternative.

\section{W(h)it her Development Economics?}

Just as some anthropologists found a home in mainstream and new institutional economics, others found a place in Marxism, the rest in original institutional economics. These analysts focused on issues that were missing in the prevailing orthodoxies. Joan Robinson, for example, took her critique of development economics in the line of Marxism (or Keynesianism), as can be seen in her book, Aspects of Development and Underdevelopment (1979/2009). Marxists too have noted the tendency for underdeveloped regions to worsen because of the dynamic of race-mediated profiteering, as shown by Cedrick Robinson (1983), Andre Gunder Frank, and (see, for example, Frank, 1966; Robinson, 1979/2011).

However, the explicit inequalities arising between groups and those forms of inequality based on group identity (race, ethnicity, or gender) have often been a weak aspect of this radical challenge. Indeed, in many Marxist circles, race has been denied, overlooked, or made worse by neglect. Even among leading African Marxists, such as Samir Amin, the question of race has not been taken very seriously, although the link between class, neo-colonialism, and imperialism has been extensively developed (see, for example, Amin, 1977). It is a charge that is also applicable to many brands of institutional economics, including the work of leading original institutional economists such as Gunnar Myrdal and J.R. Commons (Zouache, 2017; Obeng-Odoom, 2018). 
Some say the study of 'development economics' must be totally annihilated for that reason, but also because the study and practice of development economics have, in fact, caused underdevelopment (Ziai, 2015). The argument appears to be that the study of development has to give way to a new focus on 'post development' (Sachs, 2010). Advocates of this alternative seek to depose economic analysis from its exalted position in the social sciences. While well-intentioned, this approach has been widely criticised, as ignoring political-economic processes, including the dynamics of economic systems such as capitalism. The post-development, and some brands of post-colonial approaches, are also insensitive to property rights, insensitive to materialist historical processes which impinge differently and differentially on different groups, and subordinates questions of race and how they intermingle with class, gender, and ecological process (Chibber, 2013). Indeed, for these reasons, in Decolonizing Methodologies, Linda Tuhiwai Smith (2012:14), notes that "Many indigenous intellectuals actively resist participating in any discussion within the discourses of post-coloniality. This is because post-colonialism is viewed as the convenient invention of Western intellectuals which reinscribes their power to define the world'.

As with the Negritude Movement that recognised that Africans themselves had to develop their own tools of analysis and approaches to development (see, for example, Obeng-Odoom, 2015b), Africans are coming together to further develop the radical challenge to the mainstream. In seeking to decolonise existing approaches (Smith, 2012), they are calling this economics, 'stratification economics'. The currents informing this approach are currently diverse and the aspiration of these stratification economists is to make those currents even more diverse.

Nevertheless, stratification economics has a clearly defined character. The unifying features are a central focus on all forms of inequalities but especially wealth-based inequalities, a rejection of existing interpretations in the mainstream often centred on defects in the backward region or among the backward people themselves, and the systematic investigation of new explanations of inequality (see, for example, Darity, 2005, 2009; Darity and Hamilton, 2015).

This new subfield is particularly important because existing explanations of Africa's retardation reinforce the position of the privileged groups - by (a) diverting attention away from the true causes of backwardness, (b) by entrenching the pillars of privilege, and (c) by privileging remedies such as neoliberalism and neoliberalisation which help to further widen the gulf between the groups of privilege and groups of want - and, hence, the pursuit of alternative lines of analysis and policies (see, for example, Darity, 2005, 2009; Darity and Hamilton, 2015).

Stratification economists point to common defects utilised by privileged groups as a culture of poverty/backwardness, irrational behaviour, or a lack of human capital among members of the 'defective group'. Other defects range from neopatrimonialism through overpopulation/too high birth rates, and crude forms of biological and even geographical defects (see, for example, Darity and Williams, 
1985; Darity, 2005). Privileged groups, often arrogating to themselves the power of judging others, point to defects among migrants, for example, and then point to assimilation and integration, indeed to anything that would make the 'others' look like the privileged groups themselves as solutions (see, for example, Obeng-Odoom, 2017,2018 ), while stratification economists point to the unequal historical relations, the path dependencies they establish, and the ongoing forces of uneven experiences as the key points to confront and transcend.

So, stratification economics is substantially different from the economics of identity. Unlike the latter, which is premised on the idea that people freely choose their identity (Fine, 2009), stratification economics, is a tradition pioneered by economists of colour which transcends both neoclassical and Marxist development economics. This field of economics has already been recognised by including it in the JEL category, Z13 which now entails not just economic sociology or economic anthropology but also economic and social stratification (Darity, Hamilton, and Stewart, 2015: 2). The Review of Black Political Economy, the flagship journal of the National Economic Association, has been a useful vehicle for developing this subfield, but papers on stratification economics have also appeared in leading heterodox avenues around the world such as the Japan-based journal, Evolutionary and Institutional Economics Review (Obeng-Odoom, 2018). The field has helped to better understand the nature of unemployment and wealth inequalities by race, class, and gender (see, for example, Dieted, Goldsmith, Hamilton, and Darity, 2015), better understand how parents distribute their resources by skin colour in underdeveloped regions (Rangel, 2015), better understand the nature of Indigenous economies among groups that are often marginalised (Nembhard, 2014; Hossein, 2016a, 2016b, 2018) and better understand the structural basis for the marginalisation of Indigenous economies.

It remains to be seen in what ways this subfield will be developed and the nature of the body of scholarship that will be produced in stratification economics. For now, however, it is clear that, in seeking to transcend existing Africanist projects, such as those developed by Walter Rodney, Issa Shivji, Thandika Mkandawire, Walter Rodney, and Samir Amin, stratification economists have not sufficiently engaged them. As Marxists or neo-Marxists, these earlier scholars did not seek to develop new schools of economics, but their insights could help to strengthen the emerging school of stratification economics. Stratification economists have shown an aptitude to engage the work of leading African thinkers, such as Arthur Lewis, and institutionalists such as J.K. Galbraith (Stewart, 2010).

To overcome the troubling attempts to divide Africans into 'those in the North, and those in the South', they have appealed to the concept of 'Black internationalism' (Thomas, 2013). In Racial Conflict and Economic Development, Arthur Lewis, to date Africa's only Nobel Laureate in Economics, warned against such divisions, instead championing greater solidarities and more sensitivity to the conditions of Africans all over the world (Lewis, 1985, see chapters 4-6). W.E.B Du Bois also called for such broadening of engagement, in The Souls of Black Folk (1903/2014), and subsequently, demonstrated such unity when he took up Ghanaian citizenship 
and lived in Ghana until his death in 1963. More recently, James Stewart, a leading stratification economist himself, has called for 'a new progressive partnership' between "Africana Studies and Economics". It is significant that the call was published in the Journal of Black Studies (Stewart, 2008), as it signals a commitment to actually engage African writers and readers more generally.

Stratification economists have been bold, intellectually creative and imaginative by stepping out of the shadows of past intellectual currents to attempt developing a new school of thought. However, their challenge could be cast even more widely as a challenge to development economics in theory, in pedagogy, and in practice. Development economics courses in Africa's universities are wedded to neoclassical economics. In these courses, the free market is equated to capitalism, which is, in fact, a monopolistic system. Recurrent disequilibrium, the nature of African economic systems, on the other hand, is not taught. The role of economics, then, is to hide the realities of Africa (Amin, 2014). In the words of Samir Amin, 'economics thus becomes a discourse which is no longer engaged in knowing reality; its function is no more than to legitimize capitalism by attributing to it intrinsic qualities which it cannot have. Pure economics becomes the theory of an imaginary world' (Amin, 2014: 17). Amin himself prefers Marxist economics, the most visible alternative, to be taught. However, economics teachers in Africa are often sceptical about the applicability of some Marxist concepts too (Yusif, 2019), raising some of the issues discussed in Hill's critique. In turn, for many economics departments in Africa, there is a growing gap between what is taught and political-economic reality. The situation amounts, in essence, to what C.G. Woodson (1933/2018) called, the mis-education of Africans.

The case for the decolonisation African studies has become urgent $^{2}$ and Stratification economics has an opportunity to fill this void. To do so, it has to better engage the scholarship in pluralist development economics more generally (see, for example, van Staveren, 2008; van Staveren et al., 2014). It can do so by engaging more of the research by African political economists (e.g., Amanor, 2001, 2005; Nwoke, 2013a, 2013b) based in Africa, a continent that is increasingly becoming urbanised. In this regard, Akin Mabogunje's 1980 masterpiece, 'A spatial perspective on the development process' (Mabogunje, 1980/2016) could be given serious attention. African economists, and political economists more widely, could also better engage this field. The net benefit of building these bridges would be, of course, to more deeply decolonise methodologies (Smith, 2012), open economics up to the liberating pedagogical paradigms of citizenship (Obeng-Odoom, 2019a, 2019b), and develop a research agenda which is more compelling than the idealist challenge of merely developing 'southern theories' (for a detailed discussion, see Connell, 2007; Connell et al., 2018a; Connell et al., 2018b). Much like the strategy of the NonAligned Movement, in building these bridges, this new school of thought need not profess to be either left or right. It must, however, be original in its political economy.

\section{Towards the Future}

2 See, for example, the recent Editorial Introduction in African Studies Review, called 'Decolonizing African Studies' (Editor, 2018). 
Development economics continues to provide the intellectual justification for much development policy in Africa. Yet, mainstream neoclassical and new institutional development economics are also highly problematic. Marxist development economics critiques have shown the many grave limitations of orthodox or mainstream analyses, while claiming that the embrace of Marxist development economics could provide a welcome remedy.

The danger, however, is that Marxist development economics has not been as successful in doing an introspection. Could the entire field of development economics, whether mainstream (neoclassical and new institutional) or Marxist, be called into question? If so, what would be the nature of the critiques, and what alternatives could be developed?

Polly Hill sought to address these weaknesses, albeit partially. Indeed, some (e.g., Neale and Viar, 1989; Derman, 1990) have claimed that the contradictions in the critique of development economics annihilate Hill's contributions, that Hill makes no suggestion for reconstruction, or that Hill's contribution is only in terms of looking at the complexities in rural economies. Others have praised Hill for an excellent contribution (e.g., Hann and Hart, 2011). However, as this paper has shown, Hill's critique of development economics is both useful and problematic. It is certainly relevant and timely today.

The problems of Africa have become even more complex and economics even more helpless. In his book, Africa and why economists get it wrong, Morten Jerven (2015) suggests that some of the critiques offered by Hill are relevant today. Jerven's posited solution is to improve the quality of statistics, leading to far narrower alternatives than even the revisionist stance of simply combining economics and anthropology. As African political economists have shown (e.g., Obeng-Odoom, 2017), and this paper has further elaborated, the problems in mainstream development economics are far more complex. Hill recommended something else: Indigenous economics about which there has been little discussion to-day, but that alternative has its own failings too, as this paper has shown.

For now, stratification economics remains the most possible non-Marxist (although not necessarily anti-Marxist) avenue for fundamental redress. Its progress so far has been both encouraging and promising, but more time, and more work, are needed to analyse its analytical and social contributions.

\section{Acknowledgements}

Many thanks to Professor Nobuharu Yokokawa, the Editor-in-Chief of this journal, and the reviewers of The Japanese Political Economy, for constructive criticisms and suggestions for improving earlier versions of this article. The usual disclaimer applies. 


\section{Disclosure Statement}

No potential conflict of interest was reported by the author 


\section{References}

Acemoglu, D. and Robinson, J. 2012. Why Nations Fail, Crown Business, USA.

Akbulut, B., Adaman, F., and Y.M., Madra, .2015. 'The decimation and displacement of development economics." Development and Change, 46 (4): 733-761.

Alagidede, P. 2011. "Return behaviour in Africa's emerging equity markets", The Quarterly Review of Economics and Finance, 51 (2): 133-140

Alagidede, P. 2012. "Trends and cycles in the net barter terms of trade for SubSaharan Africa's primary commodity exporters." Journal of Developing Areas, 46 (2): 213-229.

Alchian, A.A. and Demsetz, H. 1973. "The Property Right Paradigm", The Journal of Economic History, 33 (1): 16-27.

Amanor, K. 2001. Land, labour and the family in Southern Ghana: A critique of land policy under neo-liberalisation. Uppsala: Nordiska Afrikainstitutet.

Amanor, K. 2005. "Night harvesters, forest hoods and saboteurs: struggles over land expropriation in Ghana". In S. Moyo, \& P. Yeros (Eds.), Reclaiming the land: The resurgence of rural movements in Africa, Asia and Latin America (pp. 102-117). London and New York: Zed Books.

Amin, S. 2014. "Understanding the political economy of contemporary Africa." Africa Development, XXXIX (1): 15-36.

Amin, S. 1977. Imperialism and Unequal Development, Monthly Review Press, London and New York.

Amin, S. 1974. Accumulation on a World Scale: A Critique of the Theory of Underdevelopment, Monthly Review Press, London and New York. 
Arndt, W. 1987. Economic Development: The History of an Idea. London and Chicago, IL: The University of Chicago Press.

Asongu, A.S. 2014. "The questionable economics of development assistance in Africa: Hot-fresh evidence, 1996-2010.' Review of Black Political Economy, 41 (4): 455-480.

Asongu, S.A. 2016. "Reinventing foreign aid for inclusive and sustainable development: Kuznets, Piketty and the great policy reversal", Journal of Economic Surveys, 30 (4): 736-755.

Asongu, S.A. and De Moor, L. 2017. "Financial globalisation dynamic thresholds for financial development: evidence from Africa", The European Journal of Development Research, 29 (1): 192-212

Austin, G. 2016. "Sub-Saharan Africa" in Joerg Baten (ed.), A History of the Global Economy from 1500 to the Present, Cambridge University Press, Cambridge: 31650.

Bauer, P.T. 1971. Dissent on Development: Studies and debates in development economics, Weidenfeld and Nicolson, London.

Bigsten, A. 2018. "Determinants of the evolution of inequality in Africa", Journal of African Economies 27 (1): 127-148.

Boettke, P.J., Fink, A, and D.J. Smith. 2012. "The Impact of Nobel Prize Winners in Economics: Mainline vs. Mainstream." American Journal of Economics and Sociology, 71 (5): 1219-1249.

Boettke P.J. C.J. Coyne., and P.T. Leeson. 2008, 'Institutional Stickiness and the New Development Economics.' American Journal of Economics and Sociology, 67 (2): 331-358.

Butler, G. 2002. 'Beyond Eclecticism: A Surplus-Orientated Approach to Political Economy', Journal of Australian Political Economy 50: 89-97. 
Chang, H.-J. 2011a. "Institutions and Economic Development: Theory, Policy and History." Journal of Institutional Economics, 7(4): doi:10.1017/S1744137410000378.

Chang, H-J, 2011b, "Reply to the Comments on "Institutions and Economic Development: Theory, Policy, and History"', Journal of Institutional Economics, 7 (4)

Chibber, V. 2013. Postcolonial Theory and the Specter of Capital, Verso, London.

Collier, P., 2006. "African Growth: Why a ‘Big Push'?”, Journal of African Economies, vol. 00, AERC Supplement 2: 188-211.

Collier, P. 2008. The Bottom billion: Why the poorest countries are failing and what can be done about it. New York, Oxford University Press.

Collier, P. 2009. Wars, Guns and Votes: Democracy in Dangerous Places, The Bodley Head, London.

Connell, R. 2007. Southern Theory: The Global Dynamics of Knowledge in Social Science, Allen and Unwin, Sydney.

Connell, R., Pearse, R., Collyer, F., Maia, J., Morrell, R. 2018a. "Negotiating with the North: How Southern-tier intellectual workers deal with the global economy of knowledge. The Sociological Review, 66(1), 41-57.

Connell, R., Pearse, R., Collyer, F., Maia, J., Morrell, R. 2018b. "Re-making the Global Economy of Knowledge: North-South Relations in New Fields of Knowledge". British Journal of Sociology, 69(3): 738-757.

Darity, W. A. Jr., 2005. "Stratification Economics: The Role of Intergroup Inequality", Journal of Economics and Finance, 29 (2): 149-53.

Darity W. A., Jr. and Williams R.M, 1985, "Peddlers Forever? Culture, Competition, and Discrimination." The American Economic Review 75 (2):256-261. 
Darity, W. Jr. 2009. 'Stratification economics: Context versus culture and the reparations controversy", Kansas Law Review, 57 (4): 795-811.

Darity, W.A., Jr and Hamilton, D. 2015. "A tour de Force in Understanding Intergroup Inequality: An Introduction to Stratification Economics." The Review of Black Political Economy 42 (1-2): 1-6.

Derman, W .1990. "Review of Development Economics on Trial: The anthropological case for a prosecution by Polly Hill", American Anthropologist, 92 (2): 537 - 538.

Du Bois W.E.B., 1903/2014. The Souls of Black Folk. Atlantic Monthly.

Editor. 2018. "Decolonizing African Studies." African Studies Review 61 (3): 1-7.

Emig, A. .1999. “Japan's challenge to the World Bank.” Japanese Economy 27 (1): $46-96$.

Epstein, T.S. 1975. "The ideal marriage between the economist's macro approach and the social anthropologist's micro approach to development studies", Economic Development and Cultural Change, 24 (1): 286 -301.

Fine, B. 2009. "The economics of identity and the identity of economics?" Cambridge Journal of Economics 33 (2): 175 - 191.

Foldvary, F.E., 2008. "The Marginalists Who Confronted Land." The American Journal of Economics and Sociology 67 (1): 89-118

Frank, A.G. 1966. "The development of underdevelopment", in K. Rajani (ed), Paradigms in Economic Development: Classic perspectives, Critiques and Reflections, M.E. Sharpe, London: 99-106.

Galbraith, J.K. 1979. The Nature of Mass Poverty, Harvard University Press, Cambridge, Massachusetts, and London. 
Gërxhani, K. 2004. "The informal sector in developed and less developed countries: A literature survey", Public Choice 120 (3/4): 267-300.

Gore, C. 1993. "Entitlement Relations and 'Unruly" Social Practices: A Comment on the Work of Amartya Sen", Journal of Development Studies 29 (3):429-460.

Gore, C. 1997. "Irreducibly Social Goods and the Informational Basis of Amartya Sen's Capability Approach." Journal of International Development 9 (2):232-250.

Hann C and Hart K, 2011, Economic Anthropology: History, Ethnography, Critique, Polity, London.

Hewitson, G. 2013. "Economics and the family: a postcolonial perspective." Cambridge Journal of Economics, 37 (1): 91-111.

Hill P, 1963, The Migrant Cocoa-Farmers of Southern Ghana: A Study in Rural Capitalism, Cambridge University Press, New York.

Hill, P. 1966. "A plea for Indigenous Economics: The West African Example." Economic Development and Cultural Change, 15 (1): 10-20.

Hill, P. 1986. Development Economics on Trial: The Anthropological Case for a Prosecution, Cambridge University Press, New York.

Hossein, C.S., 2016a, “"Big Man” politics in the social economy: A case study of microfinance in Kingston, Jamaica", Review of Social Economy 74 (2): 148-171.

Hossein, C.S., 2016b, "Money pools in the Americas: The African diaspora's legacy in the social economy". Forum of Social Economics XLV (4): 309-328.

Hossein, C.S., ed., 2018. The Black Social Economy in the Americas: Exploring Diverse Community-Based Markets. Palgrave Macmillan, New York. 
Jerven, M. 2015. Africa: Why Economists Get it Wrong. London New York: Zed Books.

Kesting, S. 2018. 'Rigor in Economics means Pluralism.' Forum for Social

Economics, DOI: 10.1080/07360932.2018.1432496.

Killick, T. 1980. "Trends in Development Economics and Their Relevance to Africa", The Journal of Modern African Studies 18 (3): 367 - 386.

Killick, T. 2010. Development Economics in Action: A Study of Economic Policies in Ghana, second edition, Routledge, London.

Klamer, A. 1989. "A Conversation with Amartya Sen", Journal of Economic Perspectives 3 (1): 135-150.

Lewis, W.A. 1985. Racial Conflict and Economic Development, Harvard University Press, Cambridge.

Macdonald, G., Spruyt, D. (2014), "Aboriginal Inequality: The Seemingly Intractable? In Susan K. Schroeder, Lynne Chester (Eds.), Challenging the Orthodoxy: Reflections on Frank Stilwell"s Contribution to Political Economy, (pp. 101-127). Berlin: Springer.

Mabogunje, A.L., 1980/2016, The Development Process: A Spatial Perspective, Routledge, London.

Marshall, A. 1890. Principles of Economics, $8^{\text {th }}$ edition. Macmillan and Co. Ltd., London.

Mayer, A, 2016, Naija Marxisms: Revolutionary Thought in Nigeria, Pluto Press, London. 
Milonakis, D. and G. Meramveliotakis. 2013. "Homo economicus and the economics of property rights: History in reverse order." Review of Radical Economics, 45 (1): 5 23.

Mkandawire, T. 2015. "Neopatrimonialism and the political economy of Economic Performance in Africa Critical Reflections." World Politics 67 (3): 563-612.

Neale, W.C. and J.B. Viar 1989, "Review of Development Economics on Trial: The anthropological case for a prosecution by Polly Hill", Economic Development and Cultural Change, 37 (4): 861-864.

Neale, W.C., 1959, "Economic accounting and family farming in India", Economic Development and Cultural Change 7 (3): 29-45.

Nembhard, J.G. 2014. Collective Courage: A History of African American Cooperative Economic Thought and Practice. State College, PA: Pennsylvania State University Press, May.

Nwoke, C.N. 2013a. "The Illusion of a Euro-American Partnership in Development with Africa," African Journal of International Affairs and Development, 17 (1\&2): 6894.

Nwoke, C.N., 2013b, Rich Land; Poor People: The Political Economy of Mineral Resource Endowments in a Peripheral Capitalist State (Ibadan: College Press).

Nyamnjoh, Francis B. 2012. "Blinded by Sight: Divining the Future of Anthropology in Africa”, Africa Spectrum, 47 (2-3): 63-92.

Obeng-Odoom, F. 2019a. "Pedagogical Pluralism in Undergraduate Urban Economics Education", International Review of Economics Education.

Obeng-Odoom, F, 2019b, "Economics, Education, and Citizenship", Australian Universities' Review 61 (1): 3-11. 
Obeng-Odoom, F. and M. Marke .2018,'The political economy of the Ebola Virus Disease', Social Change, 48 (1): 18-35.

Obeng-Odoom, F. 2015a. "Africa: On the rise but to where?" Forum for Social Economics, 44 (3): 234-250.

Obeng-Odoom, F. 2015b, "Africa's development post 2015: A critical defence of postcolonial thinking." Journal of Pan African Studies, 8 (1): 37-45.

Obeng-Odoom, F. 2016. Reconstructing Urban Economics: Towards a Political Economy of the Built Environment, Zed, London.

Obeng-Odoom, F. 2017. 'The myth of economic growth in Africa.' Review of African Political Economy 44 (153): 466-475.

Obeng-Odoom, F. 2018. "The contribution of J.R. Commons to migration analysis", Evolutionary and Institutional Economics Review 15 (1): 73-88.

Obeng-Odoom, F. 2013. "The Mystery of Capital or the Mystification of Capital?", Review of Social Economy 71 (4): 427 - 442.

Osei-Assibey, E. 2014. "Nature and dynamics of inequalities in Ghana", Development, 57, (3-4): 521-530.

Ottenberg, S. 1964. "Review of 'The Migrant Cocoa-Farmers of Southern Ghana: A Study in Rural Capitalism by Polly Hill', American Ethnologist 66: 1433- 1435

Padayachee, V. 1998. "Progressive academic economists and the challenge of development in South Africa's decade of liberation", Review of African Political Economy, 77: 431-450. 
Polanyi, K. 1957. "The economy as instituted process", in Polanyi K, Arnsberg C. M, Pearson H. W, eds., Trade and Market in the Early Empires, The Free Press, New York and Collier-Macmillan Ltd, London: 243-270.

Rangel, M.A., 2015, "Is parental love colour blind? Human capital accumulation within mixed families", Review of Black Political Economy 42 (1 and 2): 57-86.

Robinson, C, .1983. Black Marxism: The Making of the Black Radical Tradition, The University of North Carolina Press, Chapel Hill and London

Robinson, J. 1960. "Teaching economics." The Economic Weekly Annual, January: 173-175.

Robinson, J. 1979/2009. Aspects of Development and Underdevelopment, Cambridge University Press, New York.

Rodney, W. (1972/2011). How Europe Underdeveloped Africa. Baltimore, MD: Black Classic Press.

Sachs, W. (Ed). 2010. The Development Dictionary. London: Zed.

Schmelzer, M. 2016. The Hegemony of Growth - The OECD and the Making of the Economic Growth Paradigm, Cambridge University Press, Cambridge.

Sen A, 1999, Development as Freedom, Oxford University Press, Oxford.

Shin-Kap, H., L Sang-Jic, and S. Yun-Joo. 2014. 'Shifting focus in development studies: Papers in Development and Society, 1998-2013', Development and Society, 43 (1): 59-80.

Shivji, I. G. (1976). Class struggles in Tanzania. New York, NY and London: Monthly Review Press. 
Shivji, I. G., 2017, "The concept of 'working people"”, Agrarian South: Journal of Political Economy, 6(1) 1-13.

Smith, L.S., 2012. Decolonizing Methodologies, second edition, Zed, London; and Otago University Press, Dunedin.

Stewart, J.B. 2010. "Racial identity production dynamics and persisting wealth differentials: Integrating neo-institutionalist perspectives into stratification economics." The Review of Black Political Economy 37: 217 -222.

Stewart, J.B., 2008. "Africana Studies and Economics: In Search of a new Progressive Partnership." Journal of Black Studies 38 (5): 795-805.

Stilwell, F. 2018. "Editorial: What's wrong with economics?" Journal of Australian Political Economy, 80 (summer): 5-10.

Thomas, D.C. 2013. 'Cedric J. Robinson and racial capitalism: Africana liberation resistance structures and black internationalism in the twenty-first century." African Identities, 11 (2): 133-147.

van Staveren I.P., (2008). "The Gender Bias of the Poverty Reduction Strategy Framework", Review of International Political Economy, 15 (2), 289-313.

van Staveren, I.P., E. Webbink, A. de Haan \& R. Foa (2014). The Last Mile in Analyzing Wellbeing and Poverty: Indices of Social Development", Forum for Social Economics, 43 (1), 8-26

Waller, W. 2017. "Public policy adrift: Veblen's blind drift and neoliberalism', Forum for Social Economics, 46 (3): 223 - 233.

Woodson, C.G. 1933/2018. The Mis-Education of the Negro, USA.

Yusef, H. 2019. 'The need for an independent perspective: Teaching economics in Ghana", in Advancing Pluralism in Teaching Economics: International Perspectives on a Textbook Science, Routledge, London: 145-156. 
Ziai, A. 2015. 'Post-Development: Premature Burials and Haunting Ghosts', Development and Change, 46(4): 833-854.

Zouache, A. 2017. "Race, competition, and institutional change in J.R. Commons', The European Journal of the History of Economic Thought 24 (2): 341-368.

Zouache, A, 2018, "Institutions and colonisation of Africa: some lessons for French colonial economics." Journal of Institutional Economics. 14 (2): 373-391. 